\title{
Water Stress of Tallgrass Prairie Plants in Central Oklahoma
}

\author{
D.R. HAKE, J. POWELL, J.K. MCPHERSON, P.L. CLAYPOOL AND G.L. DUNN
}

\section{Abstract}

The predawn xylem water potentials of Andropogon gerardi, Schizachyrium scoparium, Panicum oligosanthes, Sporobolus asper, Ambrosia psilostachya, Psoralea tenuiflora and Solanum eleagnifolium were determined by the pressure equilibration chamber method during the 1980 growing season in a Central Oklahoma tallgrass prairie. Water potentials declined rapidly after June indicating high levels of water stress in all species. The decline in plant water potential for Schizachyrium scoparium, and to a lesser extent, Panicum oligosanthes, was much greater than that for the other 5 species. Andropogon gerardi apparently avoids dehydration by having a deep root system, whereas Schizachyrium scoparium survives in spite of a high degree of dehydration. Aboveground live biomasses declined sharply at about the same time plant water potential values decreased sharply. Results indicate plant water potential data are useful for interpreting range plant growth responses and predicting adaptability of species to harsh growing conditions.

The soil water supply in Central Oklahoma grasslands, as in the majority of all rangelands, is often inadequate for optimum plant growth throughout much of the growing season. When transpiration exceeds water absorption a decline in plant water potential results, inducing water stress (Kramer 1969, Slatyer 1967). Hsiao et al. (1976) stated that cell metabolism is markedly affected by the removal of only 10 to $15 \%$ of the water held in plant tissues at full turgor. In an extensive literature review, Hsiao (1973) noted that cell growth, wall synthesis, and protein synthesis were the cell functions initially inhibited by water stress. Under prolonged stress, cell division was also affected. Kramer (1969) stated that the degree of plant water stress is probably best expressed in terms of water potential, because this appears to be the most closely related to physiological and biochemical processes controlling growth.

Leaves or shoots often show mid-day depressions in water potentials on sunny days when atmospheric water demand are high (Hsiao et al. 1976). If adequate soil moisture is available, internal gradients produced the previous day are usually diminished at night. At that time atmospheric demand for water is low and stomatal closure prohibits transpiration allowing leaf, shoot, and soil water potentials to reach an equilibrium (Ritchie and Hinckley 1975). If soil water availability is low, plants do not regain the early morning equilibrium with soil water potentials. When this occurs, daily water stress begins to form long-term stress patterns (Brown 1977, Slatyer 1967), causing unfavorable physiological and morphological effects on the vegetation (Hsiao 1973, Hsiao et al. 1976, Boyer 1976). Ritchie and Hinckley (1975) stated that, if transpiration is sufficiently retarded, overnight equilibrium tends to be

\footnotetext{
Authors at the time of study were graduate research assistant, professor of range science, associate professor of botany, professor of statistics, and graduate research assistant, Oklahoma State University, Stillwater, 74078. Presently J. Powell is professor of range management, Department of Range Management, University of Wyoming, Laramie, and G.L. Dunn is vice president, research and development, Technical Drilling Services, Oklahoma City, Okla., D.R. Hake is a land management technician, state of Oklahoma Commissioners of the Land Office, Oklahoma City, OK.

Contribution of the Oklahoma Agricultural Experiment Station as Journal Article Number 4157 . Funding was provided by the USDA-ARS Water Quality Laboratory, Durant, Okla, Grant No. 12-14-7001-1113.

Manuscript received June $10,1982$.
}

established in soils with high soil water potentials. Thus predawn xylem water potentials are closely related to the effective soil moisture. They further asserted, as soils dry, predawn xylem water potentials become less indicative of soil moisture, but do indicate the level of water stress at which the plant begins the day and therefore remain useful as estimates of effective soil moisture.

Although the direct dependence of plant growth on plant water status is generally accepted, very few studies concerning tallgrass prairie plant species and plant water stress appear in the literature. Consequently, the main objective of this study was to determine levels and conditions of water stress in tallgrass prairie plant species during a dry growing season.

\section{Study Area}

The study was conducted on an excellent condition, tallgrass prairie in Canadian County, Okla. (elevation $600 \mathrm{~m}$ ). Annual precipitation (Fig. 1) averages $750 \mathrm{~mm}$ with nearly $80 \%$ occurring during the 208-day growing season from early April to early November (NOAA 1980). Monthly precipitation is lowest in winter and highest in spring. The highest monthly average maximum temperature of $34^{\circ} \mathrm{C}$ occurs in August and the lowest monthly average minimum temperature of $-3^{\circ} \mathrm{C}$ occurs in January. Mean monthly wind velocities vary from $18 \mathrm{~km} / \mathrm{hr}$ in July to $24 \mathrm{~km} / \mathrm{hr}$ in March. Monthly relative humidity at 0600 hours is approximately $80 \%$ throughout the year. Precipitation data were collected at the study site; all other weather date were collected at El Reno, Okla., by the National Weather Service.

The study area was on a $3 \%$ northwest-facing slope. Soils were transitional between a claypan prairie (Renfrow series) and a loamy prairie (Milan series) range site (Nance and Gray 1977). The predominant soil, Renfrow, is a member of the fine, mixed, thermic family of Vertic Argiustolls, except that the surface 0-34 cm had a loam texture. The secondary soil, Milan, is a member of the fine loamy, mixed, thermic family of Udic Paleustolls, with a 0-15 $\mathrm{cm} \mathrm{Al} \mathrm{horizon} \mathrm{and} \mathrm{a} 15-30 \mathrm{~cm}$ Bl horizon of loam texture. Both soil types are deep and well drained with slow permeability which developed from either shale or clayey and loamy sedmentary parent materials. The vegetation on these soils is dominated by Andropogon gerardi, Schizachyrium scoparium, Panicum virgatum, and Sorghastrum nutans when the range is in excellent condition (USDA 1976). Common increaser and invader species include Bouteloua curtipendula, B. gracilis, Buchloe dactyloides, annual Bromus spp., Ambrosia psilostachya, and Achillea lanulosa. A detailed description of the site was given by Dunn and Powell (1979).

The study area has a rather long and varied history of grazing, but it was never plowed. For about 30 years prior to the study the area was part of a pasture grazed moderately $(0.25$ animal unit $/$ ha $)$ by a cow/calf beef herd. In the fall of 1977 the area was mowed, but the hay not removed. The area was not grazed since 1978 .

\section{Methods}

A pressure equilibration chamber (Scholander et al. 1965, Rit- 

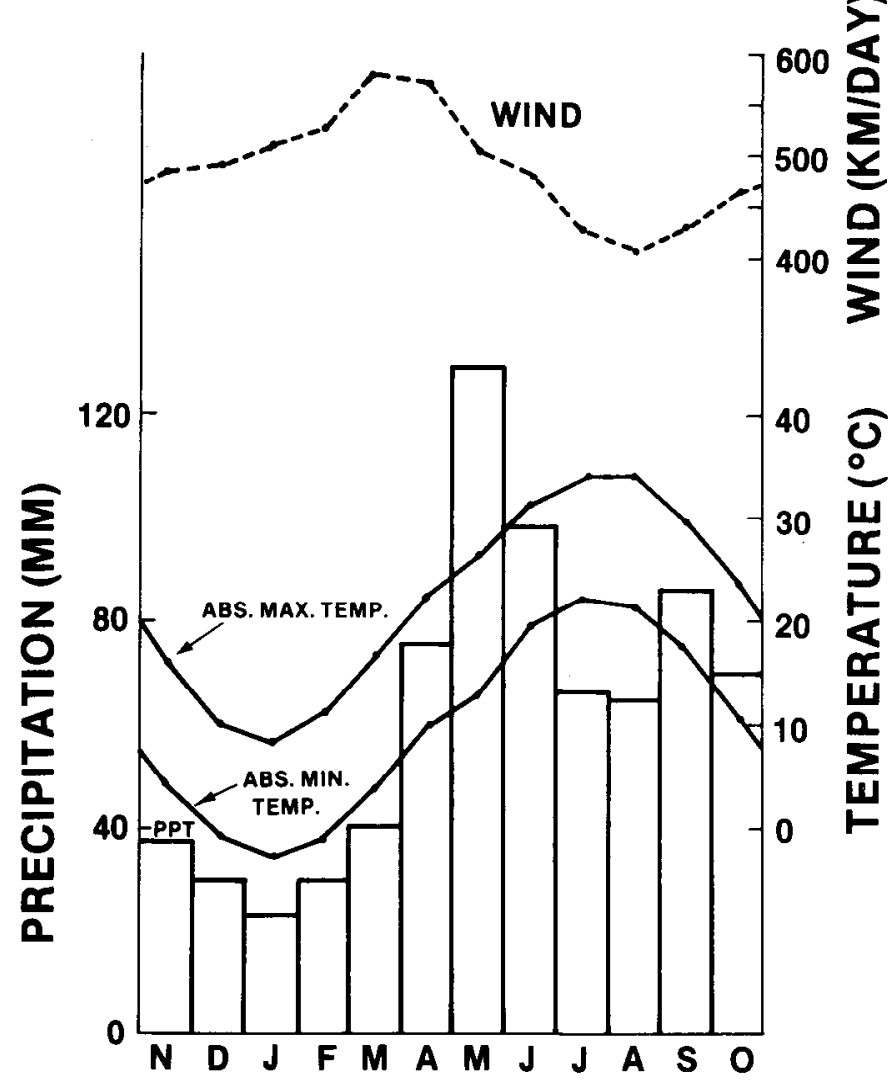

Fig. 1. Long-term average monthly precipitation $(\mathrm{mm})$, absolute maximum and minimum temperatures $(C)$ and wind $(\mathrm{km} /$ day) for study area in Canadian County, Oklahoma.

chie and Hinckley 1975) was used to determine the predawn water potentials $(\Psi)$ of 4 grasses and 3 forbs. Grasses sampled were Andropogon gerardi (ANGE, big bluestem), Schizachyrium scoparium (SCSC, little bluestem), Sporobolus asper (SPAS, tall dropseed) and Panicum oligosanthes (PAOL, Scribner's panicum). The forbs sampled were Ambrosia psilostachya (AMPS, western ragweed), Psoralea tenuiflora (PSTE, slimflower scrufpea) and Solanum eleaginfolium (SOEL, silverleaf nightshade). Experimental plants were randomly selected from a $20 \mathrm{~m} \times 20 \mathrm{~m}$ study area. Sampling began about 2 hours before sunrise and ended just before sunrise. A grass blade or a forb stem was cut from the sample plant and sealed in a pressure chamber with the cut surface of the excised blade or stem protruding through a stopper located on the top. Pressure in the chamber was increased at a constant rate of approximately $0.7 \mathrm{bars} / \mathrm{sec}$ until xylem sap appeared at the cut end. The balancing pressure was then read and recorded. This procedure was replicated 3 times on individual plants of each spccies every sampling.

The vegetation in an area adjacent to the study area was sampled throughout the 1980 growing season to coincide as closely as possible to pressure chamber sampling days. Aboveground, live biomass (ALB) and composition of the vegetation were determined using a combination of the double sampling (Wilm et al. 1944) and weight-estimate (Pechanec and Pickford 1937) methods.

The soil water content was determined in an adjacent area of similar soils and physical features using a neutron probe and access tubes (Stone et al. 1955). The area where the access tubes were located was part of another ongoing study and was subjected to moderate grazing. Soil water values presented indicate probable soil water status and movement in the study area.

Data were analyzed with an analysis of variance for a completely randomized design. Regression equations were developed for interpretation of data. Water potential models were developed for each species for the sampling period. An aboveground, live biomass model was also developed for the 1980 growing season. Water potential and ALB ( $\mathrm{kg} / \mathrm{ha}$ ) values were used as dependent variables. Independent variables for both models were days, which for calculation purposes were based upon a modified Julian year beginning I November. Unless otherwise stated, all differences were significant at the 0.05 level of probability.

\section{Results and Discussion}

Weather conditions in the summer of 1980 were hot and dry (Fig. 2). After an unusually wet spring, only $120 \mathrm{~mm}$ of rainfall

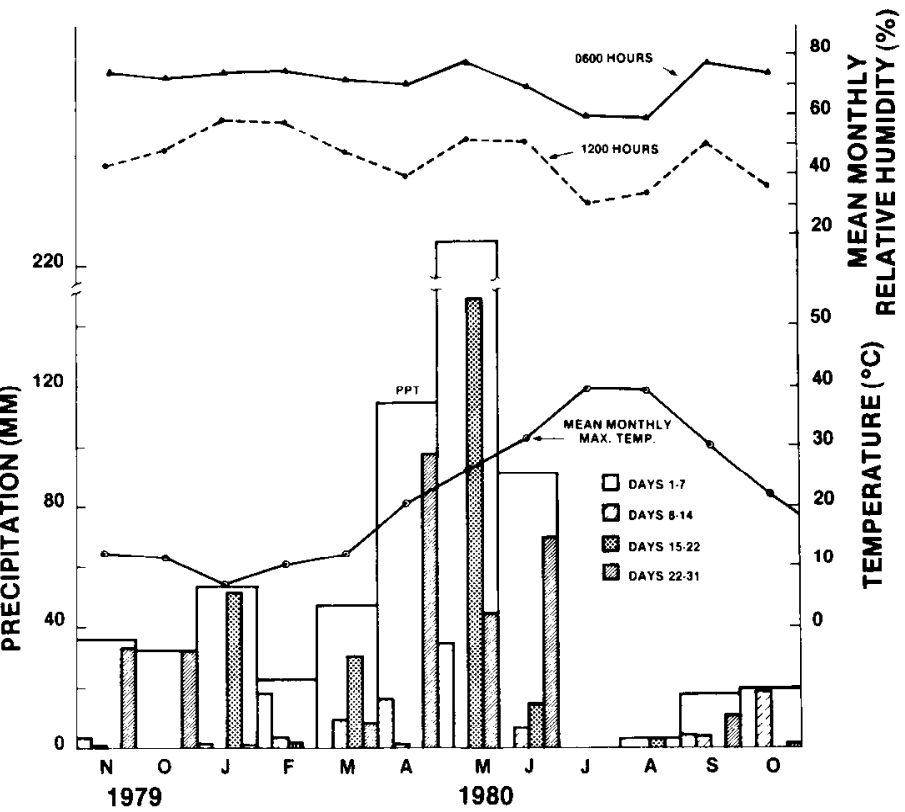

Fig. 2. Monthly precipitation $(\mathrm{mm})$, weekly precipitation $(\mathrm{mm}$, inside average monthly precipitation bars), mean monthly maximum temperature (C) and 0600- and 1200-hour relative humidity values (\%) in Canadian County, Oklahoma, 1980.

were recorded for the June-through-September period. Most (91 $\mathrm{mm}$ ) of this rainfall occurred in late June. Average monthly temperatures were $33,39,38$, and $31^{\circ} \mathrm{C}$ during June, July, August and September, respectively. The relative humidity at 0600 hours ranged from $59 \%$ in August to $77 \%$ in September

Schizachyrium scoparium had the lowest mean water potential, -48 bars, recorded 13 August (Fig. 3). The highest daily mean value recorded for the grasses, -1.0 bar, occurred 24 June in Andropogon gerardi. Water potentials for forbs decreased gradually, with pressures ranging from -1.2 bars to -12.0 bars. Significant differences $(P<.05)$ among species occurred on 6 of 10 sampling days, but on only 2 of the first 6 sampling days. Sporobolus asper $\Psi$ was greater than that of other species on 4 June, but differences were small. On 9 July, Panicum oligosanthes had the lowest $\Psi$ value, -10.0 bars. Pressures on 23 July were not significantly different although all species had significantly lower pressures than previously recorded, indicating probable reduction of available soil water. After $23 \mathrm{July}$, large differences in mean $\Psi$ occurred, with $\Psi$ for SCSC and PAOL being lower than those for the other species. Psoralea tenuiflora plants began to die and abscise from their root crowns in late July. Dunn (1977) noted that reaching a critical $\Psi$ value may cause abcission in the majority of plants in a PSTE population. The lowest $\Psi$ for this plant, -11.5 bars, occurred 6 August. No PSTE plants were found after 13 August.

In a summary of permanent wilting points of plants as quoted from studies in the literature, permanent wilting points in leaves ranged from -13 to -45 bars, with values of $-19,-17.7,-17.7$, and -34 bars for tomato, smooth brome, intermediate wheatgrass, and 


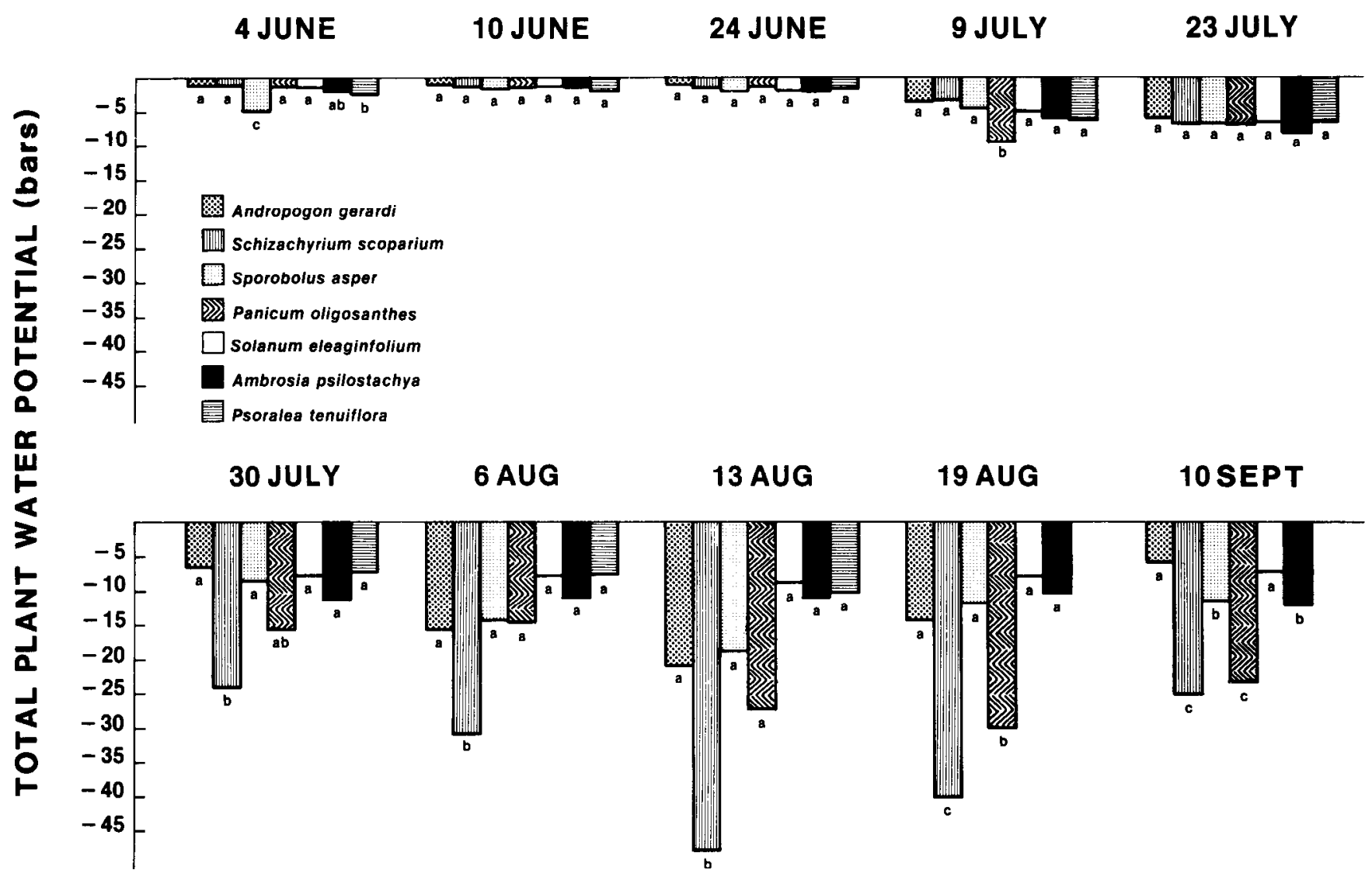

Fig. 3. Tallgrass prairie plants species'mean water potentials 4 June to 10 September, 1980, Canadian County, Oklahoma. All values with the same lower case letter are not significantly different at the 0.05 level.

cotton, respectively (Brown 1977). Brown also indicates that protoplast collapse was observed at -36.7 bars in smooth brome and -37.8 bars for intermediate wheatgrass as measured under controlled environmental conditions.

All species had decreasing seasonal $\Psi$ trends (Fig. 4). Fluctuations early in the season seem to coincide with late June precipitation events. Only SCSC and PAOL had rapid decline in predicted $\Psi$ values; these occurred in mid to late August. All other species' $\Psi$ followed a gradual decline until 10 September when species sampled had increased $\Psi$ values. This increase late in the season may have been due to light rain showers occurring several days before and on the evening before the sampling day, possibly allowing the dehydrated plant cells to regain water. It is also possible the mid-season measurements did not represent an equilibrium condition with soil water potentials. All plants became dormant late in the season, and $\Psi$ values increased slightly, possibly due to reduced water loss and passive absorption by tissue (Brown 1977, Kramer 1969). Decreased photosynthetic activity, stomatal closure, changes in solute potential and absorption of atmospheric moisture are other factors which may have also contributed to increased $\Psi$ (Boyer 1976, Hsiao et al. 1976, Slatyr 1967).

Soil water monitored with a neutron probe at $15-\mathrm{cm}$ increments to a $122-\mathrm{cm}$ depth indicated total soil water for the profile ranged from $38 \mathrm{~cm}$ in late May to $19 \mathrm{~cm}$ in mid-September (Fig. 4). The upper $45 \mathrm{~cm}$ ( $37 \%$ of profile depth) of the profile held 40 to $45 \%$ of the total soil water until early June (Fig. 5). In June, $91 \mathrm{~mm}$ of rain (91 $\mathrm{mm}$ of rain; $0 \mathrm{~mm}$ runoff) entered the soil. However, during June, evaportranspiration losses caused a large reduction in soil water in the upper $45 \mathrm{~cm}$ of the profile. As soil water levels in the upper profile decreased, mean pressure potentials became less uniform indicating different levels of stress bcginning among plant spccics.
Vegetation growth began in early April and reached peak production in early June. An aboveground biomass $(\mathrm{kg} / \mathrm{ha})$ model developed from vegetation samples estimated the peak ALB to be approximately $3,100 \mathrm{~kg} /$ ha (Fig. 6). Low summer precipitation combined with record high temperatures induced rapid depletion of soil water and slowed vegetation growth after late June. Growth patterns on grasslands dominated by warm season plants are greatly influenced by the spring and summer rainfall events (Sims and Singh 1978). Peak ALB periods in the tallgrass prairie can vary from June through August (Conant and Risser 1974, Dunn 1981, Powell et al. 1978, Sims and Singh 1978).

In a comparison of net primary production of North American grasslands, Sims and Singh (1971) found a significant inverse curvilinear relationship between the amount of belowground plant material and depth (decreasing biomass with increasing depth) on several grazed and ungrazed grasslands. The majority of grassland root biomass is located in the upper $30 \mathrm{~cm}$ of the soil profile (Dahlman and Kucera 1965, Sims and Singh 1978, Weaver 1968).

Root studies in a true prairie region near Lincoln, Nebr., by Weaver (1958) determined that ANGE roots varied from 0.5 to 3 $\mathrm{mm}$ in diameter and were found at depths greater than $2 \mathrm{~m}$. SCSC roots varied from 0.1 to $0.8 \mathrm{~mm}$ in diameter and usually grew to a maximum depth of $1.5 \mathrm{~m}$, with a possible lateral spread of $0.5 \mathrm{~m}$. During a midseason drought period in southwest Kansas, maximum root depth attained by grasses, including SCSC, on shallow soils was only $1.5 \mathrm{~m}$ (Tomanek and Albertson 1957). Many forb roots in both studies were measured at depths below $1.8 \mathrm{~m}$ ; Ambrosia psilostachya roots and the tap roots of PSTE reach depths of 1.5 to $1.8 \mathrm{~m}$ and 2.2 to $4.3 \mathrm{~m}$, respectively (Dunn 1977, Weaver 1958). Due to the high root biomass content in the upper laycrs of the soil, transpiration is high and soil water is rapidly depleted when not recharged during the growing season. Deep root penetration and high root densities are important for maximum 


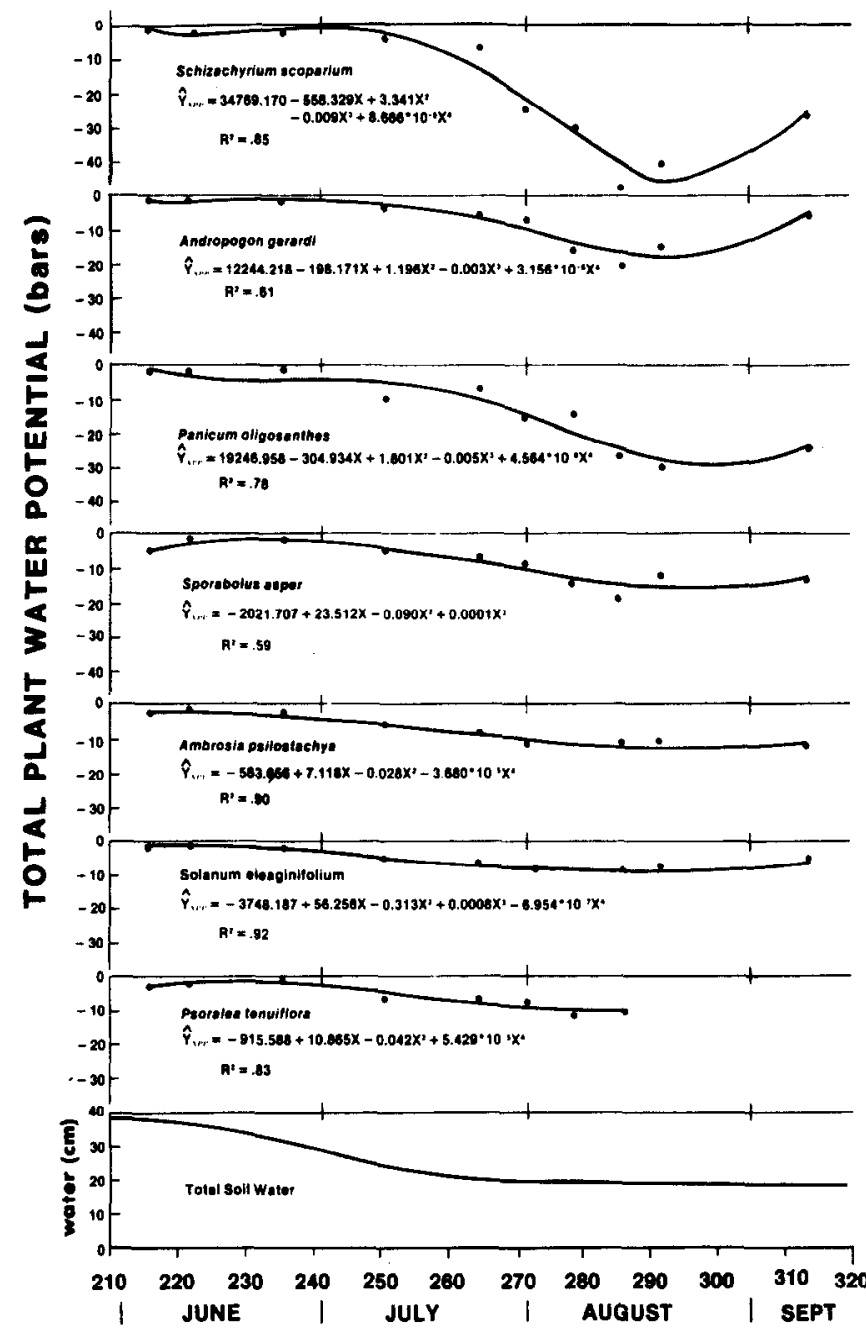

Fig. 4. Water potential (bars) models for 7 tallgrass prairie plant species and total soil water 0-122 cm depth), June-September, 1980, Canadian County, Oklahoma.

water uptake (Kramer 1969, Ritchie and Jordan 1972).

Both SCSC and PAOL have shallow root systems. Thus as the upper soil dries, water availability decreases causing higher degrees of stress. Andropogon gerardi and SPAS have relatively deep root

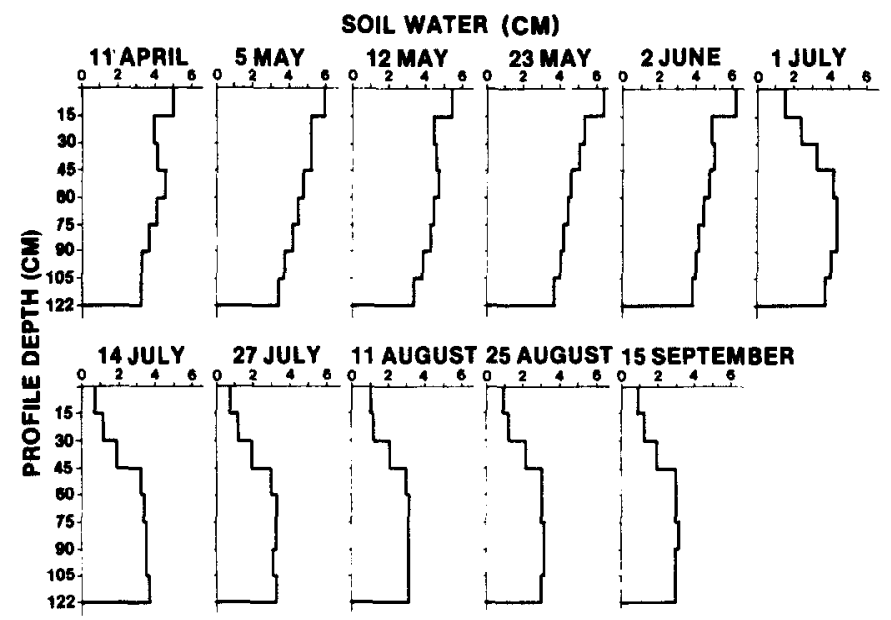

Fig. 5. Soil water content $(\mathrm{cm})$ at $15-\mathrm{cm}$ increments of a vertic argiustoll prairie soil profile between 11 April and 15 September 1980, Canadian County Oklahoma.

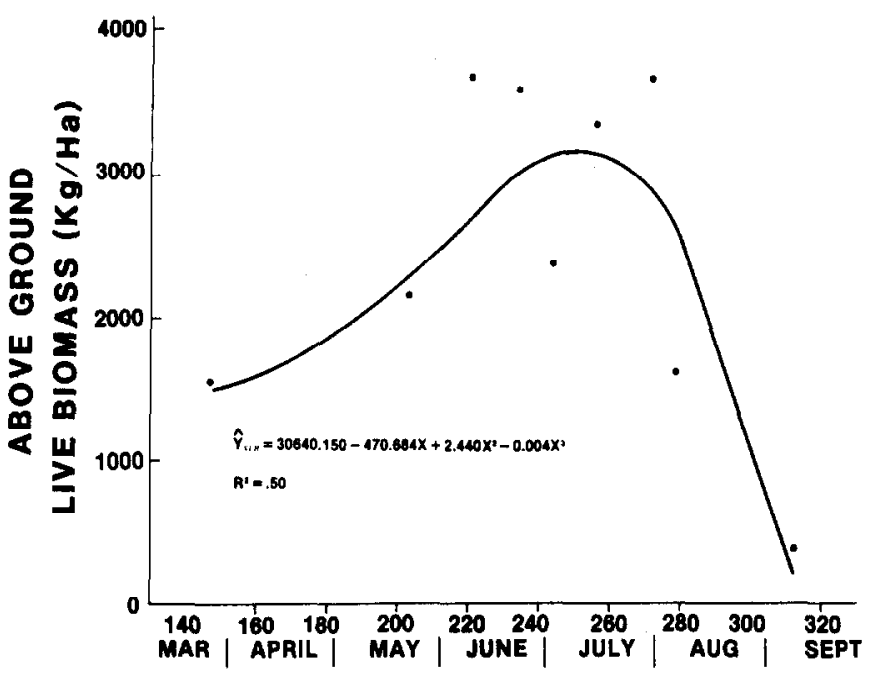

Fig. 6. Model of tallgrass prairie aboveground live biomass $(\mathrm{kg} / \mathrm{ha}$ ), March-September, 1980, Canadian County, Oklahoma.

systems which help these and other deep-rooted plants (Cook 1943) maintain lower levels of water stress during dry periods. The forbs sampled are all deep-rooted and showed only moderate levels of stress.

Rooting patterns are only one of several factors which affect water stress resistance capabilities in plants. Brown (1977) stated that plant drought resistance results from either (1) an ability to tolerate or endure stress because the protoplasm can sustain dehydration, or (2) structural and physiological adaptions that result in avoidance or postponement of the lethal effects of drought.

Low $\Psi$ values may not be uncommon for SCSC or other shallow-rooted prairie plants due to drought tolerance adaptations (Levitt 1980). This drought tolerance may be due to structural adjustments such as smaller cell size (Cutler et al. 1977) or other adaptations to prevent mechanical injury and development of disiccation resistant protoplasm (Brown 1977). However, further study of these factors in SCSC and other tallgrass prairie species is needed to determine their role in plant survival and their relationships with plant water stress and growth.

\section{Conclusions}

Plant water stress expressed in terms of water potential appears to be closely related to the physiological and biochemical processes controlling growth. In our Central Oklahoma study, 7 tallgrass species were sampled to determine $\Psi$ through a dry, hot growing season. Water potentials declined rapidly after June due to increasing temperatures and decreased soil water, causing increased levels to water stress in all species sampled. The decline in $\Psi$ for SCSC, and to a lesser extent, PAOL, was much greater than that for the other 5 species. Data analyses indicated that ANGE was less affected by soil water depletion in the upper soil profile than was SCSC. Aboveground live biomass declined sharply at about the same time plant water potential values decreased sharply. Water potential levels in these species indicate differing water relationships with their environment. Understanding these relationships may be important for determining appropriate plants for seeding different range sites, estimating optimum herbage production and grazing periods during a growing season and for other management decisions. The effect of stress on total herbage yield on grazed and ungrazed grasslands is still poorly defined. Continued investigation of this subject is greatly needed. 


\section{Literature Cited}

Boyer, J.S. 1976. Photosynthesis at low water potentials. Phil. Tran. R. Soc. Lond. B. 273:501-12.

Brown, R.W. 1977. Water relations of range plants p. 96-140. In: Rangeland Plant Physiology, (R.E. Sosebee, ed.). Range Science Series No. 4. Society for Range Management, Denver.

Conant, S. and P.G. Risser. 1974. Ca nopy structure of a tallgrass prairie. J. Range Manage. 27:313-318.

Cook, C.W. 1943. A study of the roots of Bromus inermis in relation to drought resistance. Ecology 24:169-82.

Cutler, J.M., D.W. Rains, and R.S. Loomis. 1977. The importance of cell size in the water relations of plants. Physiol. Plant. 40:255-60.

Dahlman, R.C., and C.L. Kucera. 1965. Root productivity and turnover in native prairie. Ecology 46:84-9.

Dunn, G.L. 1977. Selective aspects of the ecophysiology of slimflower scurfpea (Psoralea tenuiflora). M.S. Thesis. Fort Hays State University. Fort Hays, Kansas.

Dunn, G.L. 1981. Vegetational dynamics of a Central Oklahoma tallgrass prairie under four different management strategies. Ph.D. Diss. Oklahoma State University. Stillwater.

Dunn, G.L., and J. Powell. 1979. Effect of grassland management on range condition, run-off and water quality: Annu. Progr. Rep. Oklahoma Agri. Exp. Sta. and USDA-ARS.

Hsian, T.C. 1973. Plant responses to water stress. Annu. Rev. Plant Physiol. 24:519-79.

Hsiao, T.C., E. Acevedo, E. Fereres and D.W. Henderson. 1976. Stress metabolism: water stress, growth, and osmotic adjustments. Phil. Trans. R. Soc. Lond. B. 273:497-500.

Kramer, P.J. 1969. Plant and soil water relationships: A modern synthesis. McGraw-Hill Co., New York.

Levitt, J. 1980. Responses of plants to environmental stresses: Vol. II, Water, Radiation, Salt and Other. Academic Press, New York.

Nance, E., and F. Gray. 1977. Soil descriptions on the watershed. Water quality research watershed, El Reno Res. Sta. Oklahoma State Univ. Dep. Agro. Memo..

National Oceanic and Atmospheric Administration. 1980. Environmental Data and Information, National Climatic Center. Climatological Data: Oklahoma. Vol. 88 and 89 . Ashville, N.C.
Pechanec, J.F., and G.D. Pickford. 1937. A weight estimate method for the determination of range or pasture production. J. Agron. 29:894-904.

Powell, J.F., F.R. Crow, and D.G. Wagner. 1978. Plant biomass and nutrient cycling on a grazed, tallgrass prairie watershed. p. 216-220. In: Proc. First Internat. Rangeland Congr. (D.N. Hyder, ed.). Society for Range Management. Denver.

Ritchie, G.A., and T.M. Hinckley. 1975. The pressure chamber as an instrument for ecological research. p. 165-254. In; Advances in Ecological Research. Vol. 9. (A. Macfadyem, ed.). Academic Press, New York.

Ritchie, J.T., and W.R. Jordan. 1972. Dryland evaporative flux in a sub-humid climate. III. Soil water influence. J. Agron. 64:168-73.

Scholander, P.F., H.T. Hammel, E.D. Bradstreet, and E.A. Hemingsen. 1965. Sap pressure in vascular plants. Science 148:299-346.

Sims, P.L., and J.S. Singh. 1971. Herbage dynamics and net primary production in certain ungrazed and grazed grasslands in North America. p. 59-124. In: Preliminary Analysis of Structure and Function in Grasslands. (N.R. French, cd.). Range Sci. Dep. Science Series, Number 10. Colorado State Univ., Fort Collins.

Sims, P.L., and J.S. Singh. 1978. The structure and function of ten western North American grasslands. II. Intraseasonal dynamics in primary producer compartments. J. Ecol. 66:547-72.

Slatyer, R.O. 1967. Plant-water relationships. Academic Press, London.

Stone, J.E., D. Kirkham, and A.A. Reed. 1955. Soil moisture determination by a portable neutron scattering moisture meter. Soil Sci. Soc. Amer. Proc. 19:419-25.

Tomanek, G.W. and F.W. Albertson. 1957. Variation in cover, composition, production, and roots of vegetation on two prairies in western Kansas. Ecol. Monogr. 27:267-81.

USDA. 1976. Soil survey of Canadian County, Oklahoma. Soil Conserv. Serv. in coop. with Okla. Agr. Exp. Sta. USDA-SCS.

Weaver, J.E. 1958. Classification of root systems of forbs of grasslands and a consideration of their significance. Ecology 39:393-401.

Weaver, J.E. 1968. Prairie plants and their environment: A fifty-year study in the midwest. Univ. Nebraska Press, Lincoln.

Wilm, H.G., D.F. Costello, and G.E. Klipple. 1944. Estimating forage by the double-sampling method. J. Agron. 36:194-203.

for coverage of the world literature on agricultural research

For specimen copies of these computer-produced monthly journals and for lists of annotated bibliographies and other publications write to:
Commonwealth Bureau of

Pastures and Field Crops

Hurley, Maidenhead,

Berks SL6 5LR, UK 